Heaven and Health:

How Black, Latino, and Korean Christians View the Relationship between Faith and Health*

A Research Note

Daniel Bolger ${ }^{1}$

Cleve Tinsley $\mathrm{IV}^{2}$

Elaine Howard Ecklund ${ }^{3}$

November 14, 2017

Word Count: 6,215

Corresponding author

Daniel Bolger

Graduate Student

Rice University

Email: dan.bolger@rice.edu

713-348-3974

*Data collection funded by Faculty Initiatives Fund at Rice University, Elaine Howard Ecklund PI.

${ }^{1}$ Graduate Student, Department of Sociology, Rice University, 6100 Main St. Houston, TX 77005

${ }^{2}$ Graduate Student, Department of Religion, Rice University, 6100 Main St. Houston, TX 77005

${ }^{3}$ Herbert S. Autrey Chair in Social Sciences and Professor of Sociology, Rice University, 6100 Main St. Houston, TX 77005 


\title{
HEAVEN AND HEALTH
}

\begin{abstract}
Religious congregations have increasingly been viewed as potential access points to health care in underserved communities. Such a perspective stems from a robust literature identifying the unique civic role that churches potentially play in African American and Latino communities. Yet, research on congregational health promotion has often not considered how congregants view the connections between religious faith, physical health, and the church community. In order to further interrogate how congregants view the church's role in health promotion, we compare views on the relationship between faith and health between two groups that are overrepresented in American Christianity and underrepresented in medical careers (African Americans and Latinos) with a group that is similarly religious but comparatively wellrepresented in medical professions (Korean Americans). Drawing on data from focus groups with 19 pastors representing 18 different congregations and 28 interviews with church members, we find that churches across all three groups promote initiatives to care for the physical health of their members. Nonetheless, notable differences exist in how each group frames the interface between religious faith and physical health. African Americans and Latinos highlighted the role of faith in providing physical healing while Korean Americans saw the support of the religious community as the main benefit of their faith. Distrust of medicine was primarily articulated by members of African American churches. The results offer important implications for the future potential and nature of health initiatives in racial minority communities.
\end{abstract}

Word Count: 235

Keywords: Health, Medicine, Race/Ethnicity, Pastors, Medical Mistrust 


\section{HEAVEN AND HEALTH}

\section{INTRODUCTION}

Religious congregations are important civic institutions, particularly in racial minority communities (Sikkink and Hernandez 2003; Barnes 2005; Kim 2015). African American churches, for instance, have not only been important sites for political and social mobilization (Pattillo-McCoy 1998; Shelton and Emerson 2012), but they have also been vital institutions for the social and physical well-being of African American communities (Taylor, Chatters, and Levin 2004). Similarly, Latino and Korean American churches provide significant social capital to immigrant families; that is, they provide networks that are vehicles for resources, trust, and reciprocity (Menjivar 2003; Yeary et al. 2012; Kim 2015). While some note the ways that churches can negatively have an impact on health outcomes (Chatters et al. 2015), the unique civic role of religious congregations has not gone unnoticed by medical practitioners, as a growing body of scholarship investigates the role of churches in bridging healthcare access to minority populations (Markens et al. 2002; DeHaven et al. 2004; Catanzaro et al. 2007; Jo et. al. 2010; He et al. 2013; Allen et al. 2015).

Religious congregations are attractive partners for health care providers because of the trusting relationships they can foster with community members, as research documents distrust of health care providers in many minority communities (Reverby 2001; Armstrong et. al. 2007; Center for Disease Control 2013). Establishing trust is especially important because blacks and Latinos have been historically underserved by medical providers (Barr 2014). For example, recent work estimates that about one-quarter of American Latinos lack health insurance (National Center for Health Statistics 2016). Similarly, African Americans are significantly more likely than whites to report difficulties receiving medical care as well as delays when they do receive care (Wang et al. 2013). 


\section{HEAVEN AND HEALTH}

Yet, studies examining church-based health initiatives have largely focused on the nature and extent of congregational health programs without considering how congregants conceptualize the connections among their own faith, health, and the church community. Therefore, considering the growing literature on partnerships between medical and ecclesial communities, here we ask the following question: How do Christians that are comparatively well-represented in medicine, like Korean Americans, understand the connections between religious faith and health differently than those that are not, like African Americans and Latinos? There are certainly reasons to think these three groups might view the relationship between faith and health similarly. All three are racial or ethnic minority groups that are highly religious, with particular overrepresentation in theologically conservative Christian traditions (Pew Research Center 2015). There are also reasons to expect differences; African Americans and Latinos remain highly underrepresented in medicine while Korean Americans are part of a larger group (Asian Americans) that is overrepresented in medicine (Association of American Medical Colleges 2014). Indeed, prior research suggests that racial representation in medical professions might shape community-level distrust (Kennedy, Mathis, and Woods 2007). Similarly, medical mistrust has been documented in black and Latino communities in ways that it has not in Korean American communities (Armstrong et al. 2007). Medical mistrust, especially when considered alongside social class and educational differences among the groups, may affect the level of empowerment congregants feel to interface with medical professionals (Ryan and Bauman 2016). What we find through examining the content of focus groups with 19 pastors and interviews with 28 church members are notable similarities and differences in how African Americans and Latinos frame the health benefits of religious faith when compared to Korean Americans. This initial analysis of an understudied area provides numerous avenues for future research. 
HEAVEN AND HEALTH

\section{LITERATURE REVIEW}

The Sociohistorical Role of Churches in Minority Communities

Ample research highlights the vital role churches play in the social and political lives of historically underserved populations, especially in African American communities. Barnes (2005) notes, for example, that black churches have a prominent legacy of engaging in social activism toward addressing the life conditions and circumstances that stifle community wellbeing. Even more the Black Church — recognizing the diversity and multiplicity in this institution - has historically been one of the most important civic institutions for African Americans (Lincoln and Mamiya 1990; Pattillo-McCoy 1998; Shelton and Emerson 2012).

Although Latino churches, both Protestant and Catholic, are considerably less established as political entities than black churches, they remain far-reaching in their civic influence. Given continued immigration from Latin America, particularly that from Mexico, Latino churches often sponsor high numbers of educational initiatives (Sikkink and Hernandez 2003), including programs offering vocational training, ESL instruction, or after-school tutoring for youth (Ecklund et al. 2013). Immigration also fueled the growth of Korean American churches in the US, as some estimates suggest there is approximately one church for every 350 Korean Americans (Shin and Park 1988; Pew Research Center 2012). Such churches are largely Protestant and conservative (Ecklund 2006; Kim 2015).

\section{Religion and Health Care Access}

As civic institutions, churches often fulfill numerous functions relating to the overall physical and spiritual well-being of their parishioners. Indeed, a recent study of American churches found that nearly two-thirds offer some type of health program (Williams et al. 2015). The multifaceted nature of ministry in minority churches stems — at least in part — from a legacy 


\section{HEAVEN AND HEALTH}

of racial discrimination in US society (Goosby and Heidbrink 2013). For example, recent work highlights the high proportion of residents without health insurance in black and Latino communities (National Center for Health Statistics 2016). Similarly, scholars argue that firstgeneration Korean immigrants are also underserved by the medical community (Jo et al. 2010). And some research suggests that churches often attempt to address such disparities by providing for the material and physical well-being of members through activities like food provision and health education (Barnes 2004; Koch and Beckley 2006).

It seems also that many Christians would prefer to receive their medical information at church (Jo et al. 2008). Health initiatives, however, do not simply provide information; one study found more than 1700 types of church-sponsored outreach programs in black churches (Caldwell et al. 1995). Given that Latinos are three times more likely to be uninsured than non-Hispanic whites, health promotion has become a significant function of Latino churches (DeHaven et al. 2004). In one study of predominantly Latino Catholic parishes, about one-third had at least one church-sponsored health program and one-fifth had an active health ministry (Allen et al. 2015). Formal health programs are not the only means by which churches can promote health, as studies suggest that the perceived support of a religious community can help promote positive mental health outcomes (Krause 2011).

Public health professionals have increasingly explored initiatives leveraging the ability of churches to bridge healthcare to historically underserved communities (Anshel and Smith 2014; Rowland and Isaac-Savage 2014; Dempsey, Butler, and Gaither 2016). This includes using religious organizations to distribute information on health care screening, medical services, and health insurance. Much of the existing literature focuses specifically on how churches view potential partnerships (Markens et al. 2002; He et al. 2013; Allen et al. 2015), rather than the 


\section{HEAVEN AND HEALTH}

results of such partnerships. These studies argue that churches could serve as important partners

for medical institutions because of the respect that religious institutions and leaders hold in racial minority communities (Holt and McClure 2006; Catanzaro et al. 2007).

\section{Legacy of Medicine}

Yet, medicine also maintains a unique legacy in many racial minority communities. Experiments like the Tuskegee Syphilis Study, where public health researchers withheld treatment from poor African American men suffering from syphilis, engendered a welldocumented skepticism of the medical community (Reverby 2001; Center for Disease Control 2013). Generally, both African Americans and Latinos display higher levels of distrust in physicians and health care providers than non-Hispanic whites (Armstrong et al. 2007; CorbieSmith et al. 1999). Schnittker (2004) reports that African Americans and Latinos are also less trusting than whites of their own personal physicians.

While an increasing number of studies interrogate the relationship between religion and medicine (Anshel and Smith 2014; Rowland and Isaac-Savage 2014; Dempsey et al. 2016), particularly in the field of public health, most focus on specific populations rather than comparing multiple groups. Similarly, studies exploring partnerships between churches and health institutions focus largely on church-based health promotion rather than examining how congregations view the connections among religious faith, physical health, and the church community. The present paper begins to fill these gaps by exploring perceptions of the intersections among Christian faith, race, and medicine by looking at the content of focus groups with 19 church leaders and in-depth interviews with 28 congregation members. Such an examination provides an initial glance at how different racial and ethnic minority congregations frame the relationship between faith and health. We find that medicine and health come up often 


\section{HEAVEN AND HEALTH}

in churches, as many congregations take initiative in caring for the physical and mental health needs of their congregants, especially in communities where there is fear of interfacing with the medical community or there is actual lack of medical resources. Racial and ethnic differences in how groups view the connection between their faith and health may help inform the potential for future partnerships the medical community.

\section{METHODS}

\section{Focus Groups}

Focus groups were conducted in a large Southern city with a racially diverse population. To maximize opportunities for comparison, we chose three populations for the study: African Americans, Latinos, and Korean Americans. Despite differing levels of representation in and access to medicine, each of these three groups is highly religious. (Pew Research Center 2015). Further, they all draw on conservative Protestant views of scripture, which research suggests can shape views on some scientific and medical issues (Ellison and Musick 1995; Sherkat 2011; Chan and Ecklund 2016). Finally, each of these groups has a very different relationship with medicine and medical services, as the former two groups are historically underserved (National Center for Health Statistics 2016).

The first step in the project was developing a list of churches in the metropolitan area through connections of the research team, recommendations of religious leaders, church networks, and internet searches of local congregations. In total, 50 churches were identified and 46 faith leaders were invited to participate in a focus group. Selection criteria for churches included racial and ethnic composition, denomination, socioeconomic status (SES), size, and location. Of the 46 faith leaders contacted, 19 participated in a focus group. 


\section{HEAVEN AND HEALTH}

All focus groups were conducted in September 2015 and lasted approximately 1.5 hours each. Each participant filled out a consent form and short demographic survey. Although exact ages were not requested (age ranges were given), respondent ages ranged from 30 years old to 69 years old. Groups were semi-structured, as researchers utilized a prepared interview guide to ask questions on science, education, inequality, and medicine, among other topics. The focus groups were audio recorded and transcribed for accuracy. Transcripts were then de-identified and coded for emergent themes.

Focus groups were conducted with each group separately to maximize opportunities for interaction and comparison across-groups. In total four focus groups were conducted, two with African American pastors, one with Latino pastors, and one with Korean American pastors. The first focus group was conducted with four African American leaders, two women and two men. The second group was conducted with Latino pastors. Four church leaders attended the group, all men. The third group consisted of pastors of Korean American churches. All five attendees were men. The second African American focus group included six participants. Five men and one woman participated in the group.

Interviews

After the focus groups, one congregation from each of the racial or ethnic groups was selected for inclusion in the broader study. In selecting congregations, we identified churches typifying the traditions they represented in terms of congregation size, SES, and denomination. All three congregations selected for participation had pastors participate in the focus groups. The first church, which we call African American Baptist (AAB) church to protect the identity of the church and its members, is a Baptist church with a weekly attendance of approximately 600 members. The second church, Latino United Pentecostal (LUP) church, is a small Pentecostal 


\section{HEAVEN AND HEALTH}

church with about 70 members. The final church, Korean American Presbyterian Church (KAP), is a predominantly Korean American Presbyterian (USA) church with about 150 members.

Potential interview respondents were identified through a total of 27 participant observations at all three congregations or through the subsequent recommendations of respondents. In total, 28 interviews were completed among the three congregations - ten at $\mathrm{AAB}$, ten at LUP, and eight at KAP. Of the 28 participants, 17 were female and 11 were male. Eighteen had completed a Bachelor's degree. The average age of respondents was 37, with ages ranging from 24 to 65 years old.

Like the focus groups, we utilized a semi-structured guide. Interviews were audio recorded then transcribed for accuracy. Our analysis focused on the following questions: In a general sense, what would you say are the health needs of people in your church community? To what extent do you think faith might help address these health needs? To what extent is your church helping people in the church meet these health needs? Based on respondent reports, researchers created a list of church-based health programs for each congregation. We then selected representative quotes to illustrate the broad range of health initiatives in which each congregation engaged. We categorized responses to the question on how faith can address health needs using a modified inductive approach (Glaser and Strauss 2009); we identified themes from early interviews to create categories for analysis and then applied these categories to all subsequent interviews. More specifically, we divided responses emphasizing individual practices (i.e. personal prayer) from those emphasizing communal practices (i.e. support of the faith community). After identifying themes and categorizing responses, we selected representative quotes to illustrate each theme in the data. 


\section{HEAVEN AND HEALTH}

\section{RESULTS}

Pastors and members across all three groups reported health initiatives in their congregations, ranging from exercise classes to informational seminars. Thus, each group expressed optimism about potential partnerships between churches and medical providers. Nonetheless, group views differed on the relationship between religious faith and health. Many African American and Latino respondents emphasized the potential healing power of religious faith while Korean American respondents emphasized the role of the religious community, both in providing support and health care for physical needs. Narratives of distrust came up almost exclusively in interviews with African American respondents.

\section{Church-based Health Initiatives}

One major theme across all three groups was the high number of people, both pastors and congregants, reporting that their churches actively work to address congregational health issues. One pastor ${ }^{1}$ of a Korean church reflected his philosophy on congregational care in posing the question "If our church can't help you when...real life things happen, then ultimately what is our purpose? Are we just some spiritual institution?" With regards to actual initiatives, one African American pastor $^{2}$ shared how his church recently became more focused on health needs, explaining, "We have community workshops, health fairs, talk to [congregants] seriously about medicine and medications, dosages, mixing this with that and trying to give our members tools to converse with their own physicians." One pastor ${ }^{3}$ of an older congregation reflected that 200 people recently participated in a workshop on dementia at his church while another ${ }^{4}$ expressed interest in having someone come to his congregation to speak about developmental disorders like Autism. 


\section{HEAVEN AND HEALTH}

Congregant responses were very similar, as one African American church member ${ }^{5}$ told us "One of [the church's] themes this year is being spiritually fit, physically fit, mentally fit, you know, so we had a sermon about food, right before Thanksgiving... kind of to get people to think about their health." Congregants themselves, particularly those who worked in medicine, often played a role in promoting such holistic views of health. One Korean American congregant, ${ }^{6}$ who works as a physician, said: "Because of ...some of the health professionals we have at our church, members of the congregation can seek out advice. Not necessarily care, but advice."

\section{Connections between Faith and Medicine}

Despite similar emphases on providing holistic care for members, the groups differed in their conceptualizations of the connections between faith and health. African Americans and Latinos were the most likely to talk about the healing power of faith, as they saw individual prayer as providing not just psychological benefits but the potential for divine intervention. Such an emphasis on healing can come with downsides, however, as one African American pastor ${ }^{7}$ explained, "So on one hand there's a great positive outlook, the prayer, the belief that God can heal, that God can work it out, God can move in mysterious ways. But on the other hand, I think it can lead to some apathy as far as how we care for ourselves." Potential apathy concerned a number of pastors, as the same pastor went on to say, "On the other hand, where I see it being a challenge is I don't take as good a care of myself because I'm just going to pray and I'll be fine (laughs)...So I sometimes see it as a crutch.” For this pastor, belief in prayer, while efficacious in providing healing, can also serve as a hindrance for congregants needing medical care. One of our African American respondents ${ }^{8}$ perhaps illustrated such a perspective in saying "I mean, I think faith can help address everything, actually. If you have faith and you believe that if you pray for something that you will get what you request." 


\section{HEAVEN AND HEALTH}

Congregants from Latino churches also discussed the healing power of religious faith. For such Christians, the goal of faith was not just comfort and community, but rather the real opportunity to be healed. One member of the Latino church ${ }^{9}$ told us "every time that I'm sick, I believe that God can heal my sickness." Yet, faith in divine healing did not necessarily preclude the use of medicine. For instance, one Latina church member ${ }^{10}$ said: "I know I have a headache and I know God can heal me, but I also know that Tylenol can kick in in 30 minutes (laughs). So just because I have faith that God can heal my headache doesn't mean I'm not going to take a Tylenol." Nonetheless, for many there remains a hierarchy, as one congregant ${ }^{11}$ reflected: "I trust medicine a lot. But I think my first choice is in God."

Rather than separating faith from medicine, congregants from African American and Latino churches would often combine the two in discussing God as the creator of science and medicine. This view of God-- as the creator of science-- helped congregants substantiate trust in medicine. For instance, one congregant ${ }^{12}$ put it this way: "I think that God gives us access to certain things to help us to be better, to serve him more. Cause you don't want to come to church or you don't want to get involved in church and not have the energy to do what he needs you to do for him to build his kingdom." In this individual's mind, physical health relates to spiritual responsibility and religious mission. Similarly, a Latino pastor ${ }^{13}$ reflected God's ability to work through medical professionals in saying "I mean you know, even when one of our members is going to go through a surgery, we all pray for the doctors that are going to perform the surgery...That doesn't get in the way of us having faith that the Lord can heal a person." While also affirming the benefits of prayer, Korean American respondents tended to put more emphasis on the support provided by the church community. One Korean American pastor, ${ }^{14}$ in talking about his own congregation, said they see prayer as "kind of like a backup, 


\section{HEAVEN AND HEALTH}

just in case, as an added sort of booster." Similarly, when asked about the benefits of religious faith, one congregant ${ }^{15}$ told us: "I think mostly in terms of just realizing that [congregation members are] not alone, that there is a community out there that will go through it with you type of thing. More of a support I suppose.” Such discourse is starkly different from narratives provided by the African American and Latino congregants, as no mention is made of prayer or divine healing. Rather, faith is a "support" meant to be supplemented by medicine. Another Korean American congregant ${ }^{16}$ made this point more explicitly in saying "I think faith plays a tremendous role in coping with the stress that is related with health issues. I don't think that faith necessarily should be the primary way to deal with an actual ailment." According to this respondent, faith is just one of the tools that can facilitate healing, but not necessarily the primary one.

Some respondents even went further, saying that medical care is something that happens at their church. One pastor ${ }^{17}$ of a Korean immigrant church told us You could go to my office right now, in my closet, I've got just a ton of medicine because that's where we keep the medicine apparently in our church. It's in my closet. So, you know, the doctors in our congregation have no problem doling out medicines to anybody who needs it.

Such a statement says something about the confluence of physical and spiritual care within the pastoral role in the context of this immigrant congregation. Similarly, the pastor's later admission that this "medicine" often consisted of prescription drugs says something about the representation of medical professionals in the congregation. 


\section{HEAVEN AND HEALTH}

\section{Medical Mistrust}

Narratives regarding distrust of the medical community arose almost exclusively among African American respondents. The Tuskegee syphilis experiment seemed to have a notable legacy within this community, as the experiment came up unsolicited in the first focus group with pastors. When asked about potential partnerships with the medical community, one pastor ${ }^{18}$ told us "Building trust is major...In the black community there is an implicit memory of events like Tuskegee so we need to be careful about what we expose our congregation to." Here we see a pastor discussing how a historical event led the African American community to have high standards of trust before any partnerships can occur. Similarly, one pastor, ${ }^{19}$ in speaking to the medical community from the perspective of his members, said

'Talk to me, you know,' [congregants are] saying, 'talk to me more about how to get better, don't just keep throwing pills at me.' So that's some of the distrust I hear there. And that takes them back, so they're like 'Are they just experimenting on me? Are they just giving me this because they're experimenting on me?'

This idea of experimentation is a narrative in the African American community that seems to remain salient, as the pastor reflects that the approach of "throwing pills" might conjure memories of past experimentation.

\section{DISCUSSION}

Increased interest in partnerships between medical practitioners and churches has produced numerous studies (DeHaven et al. 2004; Catanzaro et al. 2007; Allen et al. 2015) examining views on such initiatives, but little research explores how such partnerships are shaped--or should be shaped--by congregational views on the relationship between faith and 


\section{HEAVEN AND HEALTH}

health. Moreover, even fewer studies utilize a comparative racial and ethnic framework. In comparing two different Protestant Christian groups that are underrepresented in medical professions (African Americans and Latinos) to a similarly religious group that is comparatively well-represented (Korean Americans), we found notable similarities and differences in views toward medicine. Each of the groups emphasized the prevalence of health initiatives already taking place in their congregations, while voicing different views about the ideal interface between faith and medicine. The African American and Latino respondents saw faith as providing the potential for healing. Emphasis on divine intervention was especially present among African American respondents, the only group to articulate distrust in the medical establishment. In contrast, Korean American respondents tended to frame the main benefit of faith as the support of the faith community rather than the efficacy of prayer in promoting health outcomes. Although Korean American respondents acknowledged the potential for divine healing, they saw the comfort (as well as actual help with medical care) provided by other Christians and medical professionals in the community as the most direct advantage of faith.

Such findings bridge literature from the field of public health to sociology, promoting a better understanding of the role of religious organizations in health promotion. Clearly, as other studies suggest (Anshel and Smith 2014; Rowland and Isaac-Savage 2014; Dempsey et al. 2016), health and medicine are salient topics in many communities of faith. This was seen in the sheer volume of health fairs, vaccination clinics, and other health initiatives mentioned by church members in our study. Similarly, in keeping with previous studies (Holt and McClure 2006; Jo et al. 2010; He et al. 2013), churches remain positive about the potential and need for partnerships with medical practitioners. Nonetheless, although all three populations in the study hold similar conservative Protestant theological commitments, there are differences in collective racial 


\section{HEAVEN AND HEALTH}

memory that shape how each group views the faith/health interface. Our findings help illuminate how different racial and ethnic groups might understand the benefits of such partnerships given contrasting views on the role of faith in health promotion and the legacy of medical mistrust in their communities. Future work should also investigate how socioeconomic status shapes views on the relationship between faith and health.

Although novel in the use of a comparative framework, the findings from the study are limited to a small sample size in a specific geographic area. Nonetheless, despite limitations, the exploratory nature of the study provides considerable direction for future research attempting to disentangle how religion, race, and ethnicity shape views on health and health care providers. For instance, existing research focuses narrowly on specific populations (mainly African Americans) and thus remains unable to truly understand the unique influence of religion on conceptualizations of medicine and healing. Comparative frameworks, like the one utilized in the present study, could help researchers better understand the role of religion and religious communities in health promotion as well as how such efforts differ across racial and ethnic groups. . The present study also provides direction for public health professionals interested in working with faith communities by elucidating the potential benefits and challenges of partnering with different racial and ethnic groups. Such work must move past exploring potential receptivity to partnerships to understanding how past experiences and faith commitments shape views on health and healing.

This line of research also has important implications for public-private partnerships, especially given the growing emphasis on providing social services to historically marginalized populations through religious communities (Chaves and Eagle 2016). While research suggests that churches are often preferred settings for receiving health information (Jo et al. 2008), our 


\section{HEAVEN AND HEALTH}

results suggest that policymakers should consider how distrust and religious beliefs might shape skepticism of public-private partnerships. Our findings also support prior research highlighting the importance of working with religious leaders to establish trust in historically underserved communities (Catanzaro et al. 2007). Moreover, it seems evident that different racial and ethnic groups conceptualize "health promotion" very differently based on their own theological commitments and representation in medical professions. Finally, scholars would benefit from further interrogation of how the demographic composition of religious congregations affects health promotion. For instance, more research is needed to understand how Christian medical professionals might affect ecclesial health promotion initiatives and views toward broader partnerships.

Bridging healthcare access to minority communities is no small project, although the literature is univocal in identifying churches as potential access points. Nonetheless, to understand the potential for such partnerships medical practitioners must first understand the roles of faith and skepticism in these communities. The dynamics of race and mistrust are real in religious communities, and these realities must be further interrogated by scholars and medical practitioners alike as they explore how public-private partnerships can promote health outcomes. 
HEAVEN AND HEALTH

\section{REFERENCES}

Allen, Jennifer D., Maria Idali Torres, Laura S. Tom, Sarah Rustan, Bryan Leyva, Rosalyn Negron, Laura A. Linnan, Lina Jandorf, and Hosffman Ospino. 2015. Enhancing organization capacity to provide cancer control programs among Latino churches: Design and baseline findings of the CRUZA study. BMC Health Services Research 15: 147.

Association of American Medical Colleges. 2014. Diversity in the physician workforce: Facts \& figures 2014. http://aamcdiversityfactsandfigures.org/section-ii-current-status-of-usphysician-workforce/. Accessed 19 December 2016.

Anshel, Mark, and Mitchell Smith. 2014. The role of religious leaders in promoting healthy habits in religious institutions. Journal of Religion \& Health 53(4): 1046-1059.

Armstrong, Katrina, Karima L. Ravenell, Suzanne McMurphy, and Mary Putt. 2007. Racial/ethnic differences in physician distrust in the United States. American Journal of Public Health 97(7): 1283-1289.

Barnes, Sandra L. 2004. Priestly and prophetic influences on Black Church social services. Social Problems 51(2): 202-221.

Barnes, Sandra L. 2005. Black church culture and community action. Social Forces 84(2): 967994.

Barr, Donald A. 2014. Health disparities in the United States: Social class, race, ethnicity, and health. $2^{\text {nd }}$ ed. Baltimore, MD: Johns Hopkins University Press.

Caldwell, Cleopatra Howard, Linda M. Chatters, Andrew Billingsley, and Robert Joseph Taylor. 1995. Church-based support programs for elderly Black adults: Congregational and clergy characteristics. In Aging, spirituality, and religion: A handbook, eds. Melvin A. Kimble, 


\section{HEAVEN AND HEALTH}

Susan H. McFadden, James W. Ellor, and James J. Seeber, 306-325. Minneapolis, MN: Augsburg Fortress.

Catanzaro, Ana Marie, Keith G. Meador, Harold G. Koenig, Maragatha Kuchibhatla, and Elizabeth C. Clipp. 2007. Congregational health ministries: A national study of pastors' views. Public Health Nursing 24(1): 6.

Center for Disease Control. 2013. U.S. public health service syphilis study at Tuskegee. www.cdc.gov/tuskegee/index.html. Accessed 20 May 2016.

Chan, Esther, and Elaine Howard Ecklund. 2016. Narrating and navigating authorities: Evangelical and Mainline Protestant interpretations of the Bible and science. Journal for the Scientific Study of Religion 55(1): 54-69.

Chatters, Linda M., Robert Joseph Taylor, Amanda Toler Woodward, and Emily J. Nicklett. 2015. Social support from church and family members and depressive symptoms among older African Americans. American Journal of Geriatric Psychiatry 23(6): 559-567.

Chaves, Mark, and Alison J. Eagle. 2016. Congregations and social services: An update from the third wave of the National Congregations Study. Religions 7(5): 55.

Corbie-Smith, Giselle, Stephen B. Thomas, Mark V. Williams, and Sandra Moody-Ayres. 1999. Attitudes and beliefs of African Americans toward participation in medical research. Journal of General Internal Medicine 14(9): 537-546.

DeHaven, Mark J., Irby B. Hunter, Laura Wilder, James W. Walton, and Jarett Berry. 2004. Health programs in faith-based organizations: Are they effective? American Journal of Public Health 94(6): 1030-1036.

Dempsey, Keith, Kent S. Butler, and LaTrece Gaither. 2016. Black churches and mental health professionals: Can this collaboration work? Journal of Black Studies 47(1): 73-87. 


\section{HEAVEN AND HEALTH}

Ecklund, Elaine Howard. 2006. Korean American evangelicals. New York: Oxford University Press.

Ecklund, Elaine Howard, Celina Davila, Michael O. Emerson, Samuel Kye, and Esther Chan. 2013. Motivating civic engagement: In-group versus out-group service orientations among Mexican Americans in religious and nonreligious organizations. Sociology of Religion 74(3): 370-391.

Ellison, Christopher G., and Marc A. Musick. 1995. Conservative Protestantism and public opinion toward science. Review of Religious Research 36(3): 245-262.

Glaser, Barney G. and Anselm L. Strauss. 2009. The discovery of grounded theory: Strategies for qualitative research. New Brunswick: Aldine Transaction.

Goosby, Bridget J., and Chelsea Heidbrink. 2013. The transgenerational consequences of discrimination on African-American health outcomes. Sociology Compass 7(8): 630-643.

He, Meizi, Summer Wilmoth, David Bustos, Timothy Jones, Jessica Leeds, and Zeong Yin. 2013. Latino church leaders' perspectives on childhood obesity prevention. American Journal of Preventive Medicine 44(s3): S232-S239.

Holt, Cheryl L., and Stephanie M. McClure. 2006. Perceptions of the religion-health connection among African American church members. Qualitative Health Research 16(2): 268-281

Jo, Angela M., Annette E. Maxwell, Weng K. Wong, and Roshan Bastani. 2008. Colorectal cancer screening among underserved Korean Americans in Los Angeles County. Journal of Immigrant and Minority Health 10(2): 119-126

Jo, Angela M., Annette E. Maxwell, Bryan Yang, and Roshan Bastani. 2010. Conducting health research in Korean American churches: Perspectives from church leaders. Journal of Community Health 35(2): 156-164. 


\section{HEAVEN AND HEALTH}

Kennedy, Bernice R., Christopher C. Mathis, and Angela K. Woods. 2007. African Americans and their distrust of the health care system: Healthcare for diverse populations. Journal of Cultural Diversity 14(2): 56-60.

Kim, Rebecca Y. 2015. The spirit moves west: Korean American missionaries in America. New York: Oxford University Press.

Koch, Jerome R., and Robert E. Beckley. 2006. Under the radar: AIDS ministry in the Bible Belt. Review of Religious Research 47(4): 393-408.

Krause, Neal. 2011. The perceived prayers of others, stress, and change in depressive symptoms over time. Review of Religious Research 53(3): 341-356.

Lincoln, C. Eric and Lawrence H. Mamiya. 1990. The black church in the African American experience. Durham, NC: Duke University Press Books.

Markens, Susan, Sarah A. Fox, Bonnie Taub, and Mary Lou Gilbert. 2002. Role of black churches in health promotion programs: Lessons from the Los Angeles mammography promotion in churches program. American Journal of Public Health 92(5): 805-810.

Menjivar, Cecilia. 2003. Religion and immigration in comparative perspective: Catholic and Evangelical Salvadorans in San Francisco, Washington, D.C., and Phoenix. Sociology of Religion 64(1): 21-45.

National Center for Health Statistics. 2016. Health, United States, 2015: With special feature on racial and ethnic health disparities. National Center for Health Statistics, May. https://www.ncbi.nlm.nih.gov/pubmed/27308685. Accessed 19 June 2017.

Pattillo-McCoy, Mary. 1998. Church culture as a strategy of action in the Black community. American Sociological Review 63(6): 767-784. 


\section{HEAVEN AND HEALTH}

Pew Research Center. 2012. Asian Americans: A mosaic of faiths.

http://www.pewforum.org/2012/07/19/asian-americans-a-mosaic-of-faiths-religiousaffiliation/, Accessed 27 July 2017.

Pew Research Center. 2015. America’s changing religious landscape.

http://www.pewforum.org/2015/05/12/americas-changing-religious-landscape/. Accessed 9 November 2016.

Reverby, Susan. 2001. More than fact and fiction: Cultural memory and the Tuskegee Syphilis Study. Hastings Center Report 31: 22-28.

Rowland, Michael L., and E. Paulette Isaac-Savage. 2014. As I see it: A study of African American pastors' views on health and health education in the black church. Journal of Religious Health 53: 1091-1101.

Ryan, Camille L., and Kurt Bauman. 2016. Educational attainment in the United States: 2015. United States Census Bureau. http://www.dl.icdst.org/pdfs/files/321d0ec4cab3e59091bc4c3a7d2adeba.pdf. Accessed 29 June 2017.

Schnittker, Jason. 2004. Social distance in the clinical encounter: Interactional and sociodemographic foundations for mistrust in physicians. Social Psychology Quarterly 67(3): 217-235.

Shelton, Jason E., and Michael O. Emerson. 2012. Blacks and whites in Christian America: How racial discrimination shapes religious convictions. New York: New York University Press.

Sherkat, Darren E. 2011. Religion and scientific literacy in the United States. Social Science Quarterly 92(5): 1134-1150. 


\section{HEAVEN AND HEALTH}

Shin, Eui Hang, and Hyung Park. 1988. An analysis of causes of schisms in ethnic churches: The case of Korean-American churches. Sociology of Religion 49(3): 234-248.

Sikkink, David and Edwin I. Hernandez. 2003. Religion matters: Predicting schooling success among Latino youth. Interim reports. http://eric.ed.gov/?id=ED476003. Accessed 9 July 2015.

Taylor, Robert Joseph, Christopher G. Ellison, Linda M. Chatters, Jeffrey S. Levin, and Karen D. Lincoln. 2000. Mental health services in faith communities: The role of clergy in Black churches. Social Work 45(1): 73-87.

Wang, Tze-Fang, Leiyu Shi, Xiaoyu Nie, and Jinsheng Zhu. 2013. Race/Ethnicity, insurance, income and access to care: The influence of health status. International Journal for Equity in Health 12(1): 29-35.

Williams, Malcolm V., Ann Haas, Beth Ann Griffin, Brad R. Fulton, David E. Kanouse, Laura M. Bogart, and Kathryn Pitkin Derose. 2015. Predictors of the existence of congregational HIV Programs: Similarities and differences compared with other health programs. American Journal of Health Promotion 29(6): 225-235.

Yeary, Karen Hye-cheon Kim, Songthip Ounpraseuth, Page Moore, Zoran Bursac, and Paul Greene. 2012. Religion, social capital, and health. Review of Religious Research 54(3): 331347. 


\section{HEAVEN AND HEALTH}

\section{ENDNOTES}

${ }^{1}$ KorAm31, Male, Pastor, conducted September 18, 2015

${ }^{2}$ AfAm13, Female, Pastor, conducted September 4, 2015

${ }^{3}$ AfAm46, Male, Pastor, conducted September 25, 2015

${ }^{4}$ AfAm14, Male, Pastor, conducted September 4, 2016

${ }^{5}$ AAB04, Male, Engineer, conducted January 29, 2016

${ }^{6}$ KAP07, Male, Medical Doctor, conducted April 14, 2016

${ }^{7}$ AfAm11, Male, Pastor, conducted September 4, 2015

${ }^{8}$ LUP03, Female, Teacher, conducted January 14, 2016

${ }^{9}$ LUP04, Male, Benefits Coordinator, conducted January 26, 2016

${ }^{10}$ LUP01, Female, Real Estate Agent, conducted December 11, 2015

${ }^{11}$ LUP07, Female, Physician, conducted February 17, 2016

${ }^{12}$ AAB07, Female, Legal Clerk, conducted February 14, 2016

${ }^{13}$ Lat22, Male, Pastor, conducted September 14, 2015

${ }^{14}$ KorAm35, Male, Pastor, conducted September 18, 2015

${ }^{15}$ KAP01, Male, Engineer, conducted January 24, 2016

${ }^{16}$ KAP08, Female, Psychologist, conducted May 12, 2016

${ }^{17}$ KorAm31, Male, Pastor, conducted September 18, 2015

${ }^{18}$ AfAm13, Female, Pastor, conducted September 4, 2015

${ }^{19}$ AfAm12, Female, Pastor, conducted September 4, 2015 